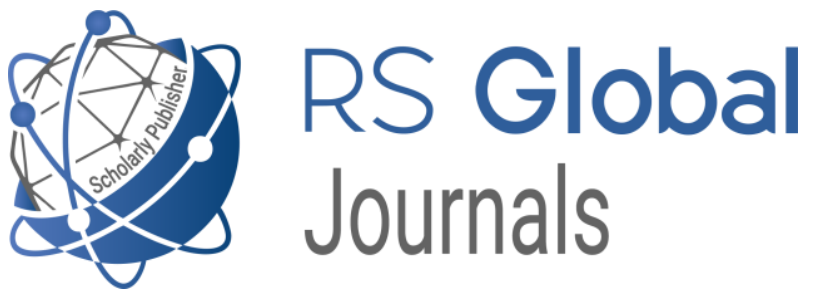

Scholarly Publisher

RS Global Sp. z O.O.

ISNI: 0000000484952390

Dolna 17, Warsaw, Poland 00-773

Tel: +48226022703

Email: editorial_office@rsglobal.pl

JOURNAL International Journal of Innovative Technologies in Social Science

p-ISSN

$2544-9338$

e-ISSN

2544-9435

PUBLISHER

RS Global Sp. z O.O., Poland

ARTICLE TITLE

СТАНОВЛЕНИЕ И РАЗВИТИЕ ИСКУССТВА ГРАФИКИ И ГРАФИЧЕСКОГО ДИЗАЙНА В АЗЕРБАЙДЖАНЕ В КОНЦЕ 19 - НАЧАЛЕ 20 ВЕКОВ

$\operatorname{AUTHOR}(\mathbf{S})$

Ашурли С. Р.

Ashurli S. R. (2021) Formation and Development of the Art of Graphics and Graphic Design in Azerbaijan at the Late of 19 -

ARTICLE INFO Beginning of 20 Centuries. International Journal of Innovative Technologies in Social Science. 3(31). doi:

10.31435/rsglobal_ijitss/30092021/7643

DOI

https://doi.org/10.31435/rsglobal_ijitss/30092021/7643

RECEIVED 19 June 2021

ACCEPTED 13 July 2021

PUBLISHED 17 August 2021

LICENSE

This work is licensed under a Creative Commons Attribution

4.0 International License.

(C) The author(s) 2021. This publication is an open access article. 


\title{
СТАНОВЛЕНИЕ И РАЗВИТИЕ ИСКУССТВА ГРАФИКИ И ГРАФИЧЕСКОГО ДИЗАЙНА В АЗЕРБАЙДЖАНЕ В КОНЦЕ 19 - НАЧАЛЕ 20 ВЕКОВ
}

\author{
Аиурли С. Р., \\ Докторант Азербайджанской Государственной Академии Художеств, Азербайджан
}

DOI: https://doi.org/10.31435/rsglobal_ijitss/30092021/7643

\section{ARTICLE INFO}

Received 19 June 2021

Accepted 13 August 2021

Published 17 August 2021

\section{KEYWORDS}

graphic art, graphic design, print graphics, industrial graphics, Azimzade, Shmerling, magazine "Molla Nasreddin".

\begin{abstract}
This article is devoted to the art of graphics in Azerbaijan of the late 19th early 20th centuries. It tell about the distinctive features of this type of fine art, the techniques of performance, directions, as well as correlation with graphic design. It tells in detail about the pre-revolutionary poster in Azerbaijan, its function, style decisions, social significance, as well as the traditions of this genre. Much attention is paid to the satirical graphics, its founders A. Azimzadeh, J. Mamedkulizadeh, O. Shmerling, I. Rotte and others, who published their works in the pages of "Molla Nasreddin".
\end{abstract}

Citation: Ashurli S. R. (2021) Formation and Development of the Art of Graphics and Graphic Design in Azerbaijan at the Late of 19 - Beginning of 20 Centuries. International Journal of Innovative Technologies in Social Science. 3(31). doi: 10.31435/rsglobal_ijitss/30092021/7643

Copyright: (C) 2021 Ashurli S. R. This is an open-access article distributed under the terms of the Creative Commons Attribution License (CC BY). The use, distribution or reproduction in other forums is permitted, provided the original author(s) or licensor are credited and that the original publication in this journal is cited, in accordance with accepted academic practice. No use, distribution or reproduction is permitted which does not comply with these terms.

Развитие графического дизайна неразрывно связано с развитием и формированием искусства графики. Их объединяли такие факторы, как стилевое решение в определенные временные периоды, социально-экономические и политические факторы, научно-технический прогресс и связанное с ним промышленное производство.

Искусство графики явилось предпосылкой формирования графического дизайна. Такие виды графического дизайна, как промышленная графика, плакатная графика, книжная графика (оформление книг) развились из соответствующих направлений искусства графики.

Графика - вид изобразительного искусства, включающий рисунок и печатные художественные изображения (гравюра, литография, монотипия и др.), основанные на искусстве рисунка, но обладающие собственными изобразительными средствами и выразительными возможностями.

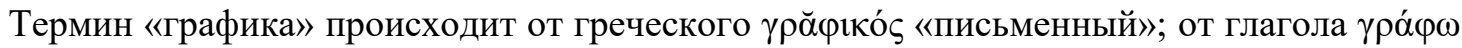
«пишу». На грани живописи и графики стоят акварель, гуашь, пастель. Графика делится на станковую (рисунок, не имеющий прикладного назначения, эстамп, лубок), книжную и газетножурнальую (иллюстрация, оформление и конструирование печатных изданий), прикладную (промышленная графика, почтовые марки, экслибрисы) и плакат. Выразительные средства графики - контурная линия, штрих, пятно (иногда цветное), фон листа (обычно белой бумаги), с которым изображение образует контрастное или нюансное соотношение. Стилистические средства графики разнообразны - от беглых, непосредственных, быстро исполненных набросков, этюдов, эскизов до тщательно разработанных композиций - изобразительных, декоративных, шрифтовых. Благодаря возможности лаконичного, резко заостренного выражения, способности быстро откликаться на события, удобство печатного размножения, 
создания циклов и серий, графика широко используется в агитационных и сатирических целях (плакат, карикатура) [4, стр. 139].

По технике исполнения искусство графики делится на рисунок и печатную графику. Рисунок выполняется карандашом, углем, сангиной, пастелью, а также красками - акварелью, гуашью, темперой. Рисунки создаются только в одном экземпляре.

В отличие от рисунка произведения печатной графики можно размножить до любого количества экземпляров с неизменным качеством. В печатной графике, в зависимости от материала графического табло, существуют различные техники: ксилография (гравюра на дереве - самая древняя техника гравюры), линогравюра (гравюра на линолеуме - возникла на рубеже 19-20 веков), гравюра на картоне (вид высокой печати), углубленная гравюра, офорт, гравюра сухой иглой, акватинта, меццо-тинто.

Основным средством графического дизайна также служит рисунок. В отличие от искусства графики графический дизайн - это исключительно художественно-проектная деятельность. Цели графического дизайна и печатной графики совпадают в части визуализации информации, предназначенной для массового распространения.

Такие направления графики, как промышленная графика, плакатная графика, книжная графика (оформление книг) в настоящее время являются составляющими графического дизайна наряду с визуальной коммуникацией, телевизионной графикой, WEB-графикой, суперграфикой $[6$, c.13].

Промышленная графика - это вид прикладной графики, обслуживающий сферы производства и сбыта промышленной продукции (товарные ярлыки, фирменные знаки, этикетки, упаковка, рекламные изделия и т.д.) [4, с.199].

Промышленная графика применяется также в сфере управления производством (деловые бумаги - бланки, конверты, товарно-сопроводительная, техническая и внутрифирменная документация).

По своим задачам промышленная графика тесно взаимодействует с промышленноторговой рекламой, зачастую являясь её составным элементом. В произведениях современной промышленной графики одинаково важную роль играют шрифт, орнамент, различные рисованные (преимущественно символического характера) и фотографические изображения, цветовое и полиграфическое решение.

В то же время широкое распространение получили такие ее формы как прейскуранты, каталоги, справочные книги, пригласительные билеты, визитные карточки, меню, купоны, открытки, фирменные бланки, календари, путеводители. Они нередко представляют собой интересные художественные решения, что немаловажно для имеджа соответствующей компании.

Плакатная реклама вошла в употребление с середины XIX века. Она дифференцировалась по назначению, по предмету рекламирования и по стилевому решению на три основные составляющие: коммерческий плакат, плакат социальной направленности плакат благотворительных обществ, собраний, различных мероприятий, посвященных филантропическим целям и плакат, информирующий о культурных событиях (театр, кино, выставки). Прослеживая развитие рекламы со второй половины XIX века и до российской революции 1917 года, можно убедиться в том, насколько энергично и оперативно эта деятельность включает в свою сферу достижения технического прогресса, в какой бы сфере жизни они ни проявлялись [2, с.6].

Рекламный процесс в Азербайджане на рубеже XIX-XX вв. охватывал всю общественную жизнь. Рекламные объявления появлялись уже не только на страницах газет и журналов, но и в таких солидных изданиях, как «Кавказский календарь», Справочный ежегодник «Баку и его район», «Бакинский календарь» и др. При этом плакатная реклама конца XIX - начала XX века следовала художественным тенденциям этого периода. Ее создатели понимали, что реклама - это серьезный продукт деятельности издателей, художников, рекламных агентств, типографий. Так, например, входивший в моду в начале XX в. стиль «art nouveau» (он же модерн, югендстиль, сецессион) нашел свое отражение не только в архитектуре того времени, но и в оформлении рекламных листков, объявлений, и даже подборе шрифтов для них.

Этот стиль оказал большое влияние на книжный дизайн и рекламу. Контрастное сочетание растительного орнамента и декоративно-силуэтных иллюстраций во многом определяло специфику облика книжной и журнальной продукции в изданиях тех лет. 
В качестве примера можно привести обложку журнала «Барабан» (№2 ноябрь 1912 , Типолитография «Каспий» И.-б. Ашурбекова), некоторые рекламные объявления в Справочном ежегоднике «Баку и его район» (изд. Шапсовича, Баку, 1913) и др.

В целом дореволюционный плакат в Азербайджане оказался наиболее художественным и профессионально оформившимся жанром, который выполнял информативную и просветительскую функции, являясь средством воздействия на зрителей разного социального уровня. Его рождение на рубеже столетий ознаменовало начало эпохи, когда театр, массовые зрелища и выставки обрели особую общественную значимость и смысл. Выполняя рекламноинформационные задачи, плакат стал неотъемлемой частью оформления городских улиц, интерьеров театров, цирков, выставочных площадок. В жанре плаката работали лучшие художественные силы. Именно ими были заложены традиции этого жанра [1].

Исследование творчества художников конца XIX - начала XX в., использующих плакатные формы, показывает, что плакат открыл перед ними новые возможности. Первые афиши и плакаты азербайджанских художников свидетельствовали о том, что графический дизайн продолжает традиции искусства. Плакатные изображения демонстрировали связь с приемами живописи и графики. Несмотря на наличие у каждого из художников собственного творческого стиля, существовало объединяющее их начало. Художестенное кредо мастеров, работающих в жанре плаката, это сочетание декоративности, монументальности, неожиданных композиционных приемов, стремление к выразительности минимальными средствами.

В Азербайджане в конце XIX - начале XX вв. бурно развивалась промышленная нефтедобыча, шло ускоренное развитие капитализма. Этот процесс сопровождался активным развитием общественно-политической мысли, что, в свою очередь, создало предпосылки и для развития сатирической графики. Ее возникновение и развитие связано с деятельностью журнала «Молла Насреддин», редактором и издателем которого был видный писатель и публицист Джалил Мамедкулизаде. Широкую деятельность в рамках упомянутого журнала развернули художники Азим Азимзаде, Халил Мусаев, Карл Роттер и Оскар Шмерлинг, в их творчестве ярко отразились общественно-политические проблемы эпохи. Выход этого журнала ознаменовал начало нового этапа развития азербайджанской печати. Под его влиянием наравне с сатирическими журналами «Бахлул» (1907), «Занбур» (1909-1910), «Мират» (1910), «Ары» (1910-1911), «Кялнийат» (19121913), «Лякляк» (1914), «Тути» (1914-1917), «Мезели» (1914-1915), «Бабайи-Эмир» (1915-1916), «Тартан-Партан» (1918), «Шейпур» (1918-1919), «Зянбур» (1919), «Мешел» (1919-1920) стали издаваться сатирические журналы и на русском языке, в числе которых следует отметить «Джигит» (1907-1918), «Вай-вай» (1908), «Бакинское горе» (1908-1909), «Бич» (1909-1915), «Адская почта» (1909-1910), «Бакинские стрелы» (1910), «Барабан» (1912-1913) [3].

Еженедельный иллюстрированный журнал «Молла Насреддин», издававшийся с 7 апреля 1906 года в Тифлисе, был первым сатирическим журналом в мусульманском мире и приобрел широкую известность на всем Ближнем Востоке. Среди азербайджанских печатных органов того времени он отличался более резкой сатирической направленностью. Издание журнала «Молла Насреддин» повлияло не только на национальную прессу, но и внесло оживление в повседневную жизнь народа [5].

Журнал вывел карикатуру как самостоятельный жанр в народные массы, на арену борьбы, и карикатура превратилась в могучее средство пропаганды передовых идей. Сатирические рисунки различной тематики, изображаемые посредством простых и ясных форм, легко воспринимались всеми слоями населения.

Основоположник отечественной сатирической графики А. Азимзаде создавал острые карикатуры и шаржи, изобличающие общественное неравенство, невежество и фанатизм, гнет царизма. Своей актуальностью, а также национальным колоритом отличаются знаменитая серия «Сто типов», акварельные работы, посвященные свободе женщин, атеизму и политическим мотивам. Среди наиболее успешных работ А. Азимзаде - его иллюстрации к сборнику произведений М.А. Сабира «Хопхопнаме» [7].

В 7-м номере журнала «Молла Насреддин» (1906 г.) была опубликована первая карикатура Азима Азимзаде, которую можно однозначно назвать отправной точкой будущих творческих успехов художника. Именно многогранное творчество Азимзаде стало определять лицо журнала.

В дальнейшем Азим Азимзаде сотрудничал с журналами «Барабан», «Бич», «Мезели», «Тути» и «Бабайи-Эмир», а в 1919 году - с журналом «Зянбур», публиковал на их страницах 
карикатуры и рисунки. Известно, что в этот период художник, публикуя карикатуры, обрел немало недоброжелателей, агрессивно коментирующих его деятельность. Несмотря на многочисленные угрозы, раздававшиеся в его адрес, художник остался верен избранному пути. Примером тому могут послужить его иллюстрации ко второму, посмертному изданию (1914 г.) известной сатирической поэмы Мирзы Алекпера Сабира «Хопхопнаме», где как в зеркале была отражена та эпоха. 24 цветные иллюстрации, вошедшие в это издание, произвели в обществе такой резонанс, что художника стали называть «Сабир азербайджанской живописи». В этих иллюстрациях, представляющих четкий графический комментарий к сабировским стихотворениям, выразился весь творческий потенциал большого художника. Так же и к третьему изданию «Хопхопнаме», осуществленному в 1922 году, А. Азимзаде сделал более 20 запоминающихся иллюстраций, которые считаются лучшими образцами азербайджанской книжной графики XX века. Эти рисунки, как сейчас принято говорить, явились своего рода «фирменным стилем» творчества Азима Азимзаде.

Среди первых азербайджанских карикатуристов были и выпускники Мюнхенской и Петербургской академий художеств О. Шмерлинг и И. Роттер, которые внесли большой вклад в формирование и развитие этого жанра в Азербайджане. Творчество этих художников, немцев по национальности, ярко отражает историю азербайджанского народа, его дух, повседневный быт. Идейным вдохновителем работ художников был редактор журнала Джалил Мамедкулизаде, который направлял их творчество, предоставляя первые эскизы, нарисованные в карманном блокноте. Несмотря на то, что идеи сатирических рисунков и карикатур принадлежали Дж. Мамедкулизаде, О. Шмерлинг и И. Роттер сумели вдохнуть в них вторую жизнь. Каждая тема, каждый эскиз, предложенный редактором, возвышались до уровня графического произведения [3]. Профессионализм художников дал возможность этим произведениям, выделяющимся совершенством рисунка, пройти испытание временем.

Таким образом, в системе ценностей художественной культуры на этапе становления графического дизайна центральное место занимало искусство. Именно поэтому графический дизайн, в лице его основоположников ориентирован на высокое художественное мастерство и воспитание хорошего вкуса.

\section{ЛИТЕРАТУРА}

1. Алескерова Ирада. Этапы развития азербайджанской карикатуры. Журн. «Культура», №2(50), 2011.

2. Богачева. Н.М. Реклама, ее возникновение и некоторые сведения из истории развития. Министерство торговли СССР. М., 1969. - 22с., ил.

3. Гаджизаде Б.К. Этапы развития азербайджанской карикатуры. Retrieved from http://cartoonia.ru/ru/library/articles/etapy-razvitiya-azerbaidzhanskoi-karikatury-bk-gadzhizade/

4. Гасанов Р.М., Абдуллаева Н.Д., Бакирова Т.Ш. Толковый словарь терминов дизайна. Изд-во «Адильоглу», Баку, 2005. - 251с.

5. Джафарзаде А. Журнал "Молла Насреддин" против международной реакции. //Ингилаб вэ меденийят. - 1951.- № 8.

6. Основные термины дизайна. Краткий словарь-справочник. Под ред. Л.А.Кузьмичева. М., ВНИИТЭ, 1989. - 88c.

7. Retrieved from http://www.azerbaijan.az/_Culture/_FineArts/fineArts_02_r.html

8. Hacızadə B. Azərbaycanın karikaturaçı rəssamları. Bakı, «Maarif», 2001, $120 \mathrm{~s}$. 